\title{
HUBUNGAN KONSEP DIRI TERHADAP PRESTASI BELAJAR PADA SISWA SMP NEGERI 2 TANJUNG KABUPATEN LOMBOK UTARA
}

\author{
Ani Endriani ${ }^{1}$, Yulianti $^{2}$ \\ Jurusan Bimbingan Konseling, FIPP UNDIKMA \\ E-mail :aniendriani20@gmail.com
}

\begin{abstract}
Abstrak. Konsep diri adalah pandangan dan perasaan kita tentang diri kita, yang berhubungan dengan aspek fisik, sosial dan psikologis, pandangan dan perasaan kita tentang diri kita, mencakup persepsi individu mengenai karakteristik fisik, melainkan juga penilaian mengenai apa pernah dicapai, dan apa yang dijalani. Sedangkan rumusan masalahan dalam penelitian ini adalah: apakah ada "Hubungan Konsep Diri terhadap Prestasi Belajar pada Siswa Kelas VII SMP Negeri 2 Tanjung Kabupaten Lombok Utara".? Adapun tujuan dalam penelitian adalah:"Ingin mengetahui Hubungan Konsep Diri Terhadap Prestasi Belajar Pada Siswa Kelas VII SMP Negeri 2 Tanjung Kabupaten Lombok Utara. Tekhnik yang di gunakan dalam penelitian adalah: menggunakan proposional random samplingd. Dengan jumlah populasi 200 , sampe ${ }^{25} /{ }_{100} \times 200=50$ orang. jadi jumlah sampel penelitian ini adalah 50 orang. Sedangkan metode yang digunakan untuk memperoleh data dalam penelitan ini adalah: metode angket sebagai metode pokok sedangkan metode observasi, wawancara, dokumentasi sebagai metode pelengkap dengan analisis data menggunakan rumus product moment. Hasil analisis data yang diperoleh dalam penelitian ini adalah: hipotesis alternative ( $\mathrm{Ha})$ diterima dan hipotesis no (Ho) ditolak sebab nilai $r$ hitung lebih besar dari pada $r$ tabel dengan signifikan 5\% (3,070>0,279) dengan demikian Hubungan Konsep Diri Terhadap Prestasi Belajar Pada Siswa Kelas VII SMP Negeri 2 Tanjung Kabupaten Lombok Utara. signifikan.
\end{abstract}

Kata kunci: Konsep Diri, Prestasi Belajar

\section{PENDAHULUAN}

Pendidikan merupakan salah satu upaya untuk mengembangkan kualitas sumber daya manusia yang pada umumnya wajib dilaksanakan oleh setiap Negara.Hal ini mengarahkan pendidikan sebagai program strategis jangka panjang yang pada penyelenggaraannya harus mampu menjawab kebutuhan dan tantangan secara nasional. Dalam Kamus Besar Bahasa Indonesia diuraikan bahwa pendidikan adalah "proses pengubahan sikap dan tata laku seorang atau kelompok orang dalam usaha mendewasakan manusia melalui upaya pengajaran dan pelatihan; proses, cara, perbuatan mendidik. Dalam proses belajar konsep diri sangat di utamakan,karena menentukan hasil belajar siswa, tanpa konsep diri maka prestasi 
belajar siswa belum bisa tercapai secara optimal. Berdasarkan latar bekang di atas, bahwa masih banyak siswa yang kurang memiliki konsp diri positifsehingga peneliti sangat tertarik memilihdengan judul Hubungan Konsep Diri Terhadap Prestasi Belajar Siswa Pada Siswa SMP Negeri 2 Tanjung Kabupaten Lombok Utara.

\section{KAJIAN LITERATUR}

\section{Konsep Diri}

Konsep diri berasal dari bahasa inggris yaitu self concept merupakan suatu konsep mengenai diri individu itu sendiri yang meliputi bagaimana seseorang memandang, memikirkan, dan menilai dirinya sehingga tindakan tindakannya sesuai dengan konsep tentang dirinya tersebut.Menurut Rahmat (2003 : 99), konsep diri adalah pandangan dan perasaan kita tentang diri kita. Persepsi tentang diri ini boleh bersifat psikologi, sosial dan fisik. Pendapat yang hampir sama dikemukakan oleh Sugiyo (2005 : 49), bahwa konsep diri adalah gambaran mengenai dirinya sendiri baik yang berhubungan dengan aspek fisik, sosial dan psikologis. Selain itu Pearson (1991) dalam Sugiyo (2005 : 49), menyatakan bahwa konsep diri yaitu kesan individu yang relatif stabil mengenai diri sendiri, tidak hanya mencakup persepsi individu mengenai karakteristik fisik, melainkan juga penilaian mengenai apa pernah dicapai, dan apa yang dijalani.

Berdasarkan pendapat para ahli diatas peneliti dapat menyimpulkan bahwa konsep diri adalah: pandangan dan perasaan kita tentang diri kita, yang berhubungan dengan aspek fisik, sosial dan psikologis, pandangan dan perasaan kita tentang diri kita, mencakup persepsi individu mengenai karakteristik fisik, melainkan juga penilaian mengenai apa pernah dicapai, dan apa yang dijalani.

\section{Aspek-aspek Konsep Diri}

Menurut Widjajanti (dalamhttp aspek-aspek dalam konsep diri), mengemukakan aspek konsep diri yang meliputi ;(1). Aspek fisik, meliputi penilaian individu terhadap segala sesuatu yang dimilikinya, seperti tubuh, pakaian, benda miliknya, dan lain sebagainya, (2).Aspek psikis, meliputi pikiran, perasaan, dan sikap yang dimiliki individu terhadap dirinya sendiri, (3).Aspek sosial, meliputi peranan sosial yang dimainkan individu dan penilaian individu 
terhadap peran tersebut, dan (4).Aspek moral, meliputi nilai dan prinsip yang memberi arti serta arah bagi kehidupan seseorang.

\section{Faktor-faktor Yang Mempengaruhi konsep Diri}

Konsep diri seseorang dipengaruhi oleh faktor internal dan faktor eksternal. Marsh dan Burger (dalam Alex sobur, 2003: 517). Dari berbagai faktor yang mempengaruhi konsep diri seseorang, maka peneliti mengambil kesimpulan bahwasanya faktor-faktor utama yang mempengaruhi konsep diri pada mahasiswa adalah :1. Faktor internal yang meliputi: a. Intelegensi, motivasi dan emosi (karakter mahasiswa). b. Kompetensi personal (kemampuan dan keterampilan tertentu yang dimiliki oleh mahasiswa). c. Episode dalam kehidupan (pengalaman mahasiswa yang berpengaruh besar dalam hidup, seperti masa sekolah). d. Episode keberhasilan dan kegagalan (pengalaman dalam memanfaatkan peluang, misalnya pengalaman berorganisasi). e. Keberhasilan personal (pengalaman berprestasi). f. Status kesehatan (riwayat kesehatan mahasiswa). g. Penampilan fisik (kepercayaan diri mahasiswa terhadap penampilannya). h. Aktualisasi diri, (misalnya hobi mahasiswa).i. Persepsi tentang kegagalan (pengalaman kegagalan di masa lalu).j. Jenis kelamin. k. Religiusitas,l. Usia. dan m. Tingkat stres. 2. Faktor Eksternal yang meliputi:a. Orangtua dan keluarga (hubungan dengan orangtua, termasuk tempat tinggal individu).b. Teman sebaya (misalnya teman bermain/peers,teman kuliah, dan lainlain). c. Peran pendidik (misalnya peran dosen, pementor, pembina, dan lain-lain).d. Kebudayaan (misalnya suku, agama, adat istiadat, dan lain-lain) e. Status sosial (misalnya status pendidikan orangtua, pendapatan orangtua, dan lain-lain) dan f. Pengalaman interpersonal (misalnya riwayat pembinaan yang pernah dilakukan).

\section{Faktor-faktor yang Mempengaruhi Prestasi Belajar}

Dalam buku Media Pengajaran, hal ini sesuai dengan pendapat yang telah dikemukakan oleh Richard clark sebagai berikut: "Bahwa hasil belajar siswa disekolah $70 \%$ dipengaruhi oleh kemampuan siswa dan 30\% dipengaruhi oleh faktor lingkungan (Sudjana, 1992:39).

Faktor internal meliputi: a). Aspek fisiologis. Mencakup kondisi umum jasmani dan tonus yang menandai tingkat kebugaran organ-organ tubuh dan sendi- 
sendinya, dapat mempengaruhi semangat dan intensitas siswa dalam mengikuti pelajaran, b) Aspek psikologis. Mencakup (1) intelegensi siswa, yakni tingkat kecerdasan siswa; (2) sikap siswa, yakni gejala internal yang berdimensi afektif berupa kecenderungan untuk meraksi atau merespon dengan baik secara positif maupun negatif; (3) bakat siswa, yakni kemampuan potensial yang dimilik siswa untuk mencapai keberhasilan pada masa yang akan datang; (4) minat siswa, yakni kecenderungan dan kegairahan yang tinggi atau keinginan yang besar terhadap sesuatu; serta (5) motivasi siswa, yakni keadaan internal yang mendorong siswa untuk berbuat sesuatu.

Faktor eksternal dapat dipahami sebagai unsur-unsur yang terdapat disekitar siswa.Faktor eksternal yaitu faktor yang timbul dari luar diri pribadi siswa itu sendiri. Faktor eksternal, meliputi: a) Lingkungan sosial, seperti guru, para tenaga kependidikan, sifat orang tua, masyarakat, ataupun teman-teman sekelas dapat mempengaruhi semangat belajar siswa. b) Lingkungan nonsosial, yang mencakup sarana dan prasarana sekolah, alat-alat belajar, letak dan tempat tinggal, serta situasi dan kondisi lingkungan pada umumnya pada saat siswa melakukan aktivitas belajar

Sejalan dengan penjelasan beberapa pendapat di atas, maka dalam penelitian ini peneliti berkecenderungan kepada pendapat yang menyatakan bahwa faktor-faktor yang mempengaruhi belajar jumlahnya, tetapi dapat digolongkan menjadi dua golongan saja, yaitu: faktor internal dan faktor eksternal. Faktor internal adalah faktor yang ada dalam diri individu yang sedang belajar, sedangkan faktor eksternal adalah faktor yang ada di luar individu.

\section{METODE PENELITIAN}

Penelitian ini merupakan suatu penelitian korelasi atau penelitian hubungan adalah penelitian yang dilakukan untuk mengetahui tingkat hubungan antara dua variabel yaitu variabel x (konsep diri ) dan variabel y (prestasi belajar), tanpa melakukan perubahan atau manipulasi. Desain rancangan penelitiannya adalah sebagai berikut :

\begin{tabular}{|c|}
\hline Variabel X \\
Konsep Diri \\
\hline
\end{tabular}

\begin{tabular}{|c|}
\hline Variabel Y \\
Prestasi Belajar
\end{tabular}




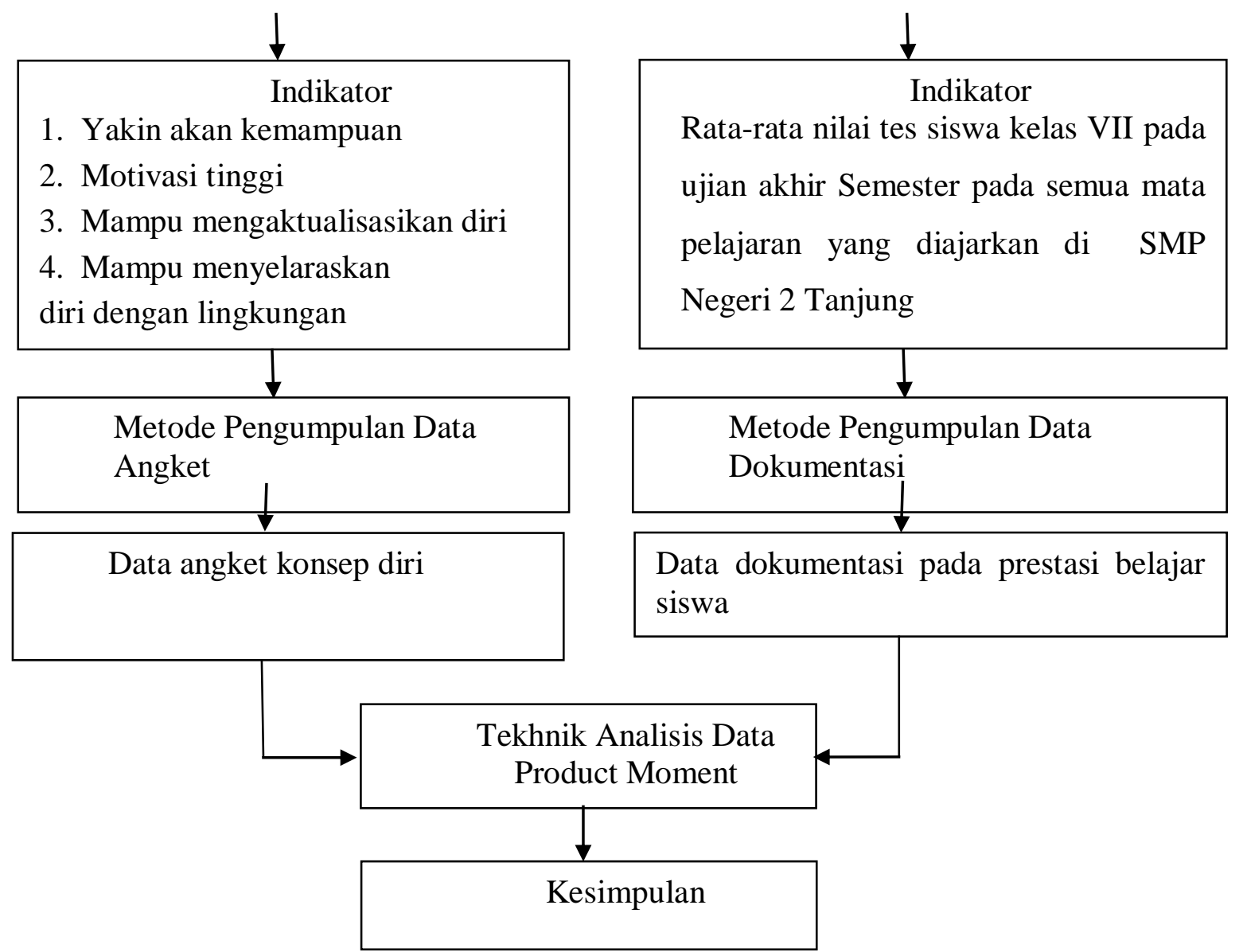

Gambar : 01 Rancangan Penelitian Korelasi Antara variabel X dan Variabel Y

Berdasarkan uraian di atas, peneliti mengambil 25\% dari jumlah populasi 200 siswa, jadi sampelnya adalah: 50 siswa. Sedangkan tekhnik pengambilan sampel pada penelitian ini dengan menggunakanteknikproposional rondom sampling yaitu pengambilan sampel secara acak dengan cara undian karena setiap populasi memiliki kesempatan yang sama untuk dijadikan sampel penelitian. Metode pengumpulan data adalah menggunakan angket sebagai metode pokok, sedangkan metode dokumentasi sebagai metode pelengkap. Adapun indikator penilaian angket konsep diri yang disebarkan, dilakukan dengan skala tiga yang terdiri dari 3 (tiga) alternatif jawaban (option) yaitu: apabila responden menjawab "a" (ya) skor nilai $=3$, apabila responden menjawab " $b$ " (kadang-kadang) skor nilai $=2$ dan apabila responden menjawab "c" (tidak) skor nilai $=1$. Data hasil angket ini kemudian diolah dan dianalisis secara intensif dan sistematis atau teratur sesuai 
dengan keadaan yang sebenarnya. Metode analisis data yang digunakan dalam penelitian ini adalah menggunakan rumus korelasi product momentsebagai berikut:

$$
r_{x y}=\frac{\Sigma x y}{\sqrt{\left(\Sigma x^{2}\right)\left(\Sigma y^{2}\right)}}
$$

Keterangan:

$\mathrm{xy}=$ Koefisien korelasi product moment

$\Sigma x^{2}=$ jumlah dari variabel $\mathrm{x}$ kuadrat

$\Sigma y^{2}=$ jumlah dari variabel y kuadrat

$\Sigma x y=$ jumlah dari hasil kali variabel $\mathrm{x}$ dan $\mathrm{y}$ (Sugiyono, 2010: 228).

\section{HASIL PENELITIAN}

Setelah dilakukan penelitian dan mengumpulkan data hasil penelitian tentang angket hubungan antara konsep diri dengan prestasi belajar pada siswaSMP Negeri 2 Negeri Tanjung Kabupaten Lombok Utara, kemudian dilakukan analisis untuk mendapatkan hasil dan gambaran dari indikator penelitain. Berdasarkan hasil penyebaran angket hubungan antara konsep diri dengan prestasi belajar Pada SiswaSMP Negeri 2 Negeri Tanjung Kabupaten Lombok Utara, dari hasil nilai data konsep diri sebesar 2161 dan hasil data dokumentasi Rata-rata nilai tes siswa kelas VII pada ujian akhir Semester pada semua mata pelajaran yang diajarkan di SMP Negeri 2 Tanjung sebesar 3354.

Adapun langkah-langkah yang ditempuh dalam pengujian hipotesis ini sesuai dengan yang telah dicantumkan pada bab sebelumnya adalah sebagai berikut :

1) Merumuskan Hipotesis Nihil (Ho)

Hipotesis yang diajukan dalam penelitian ini adalah hipotesis alternatif (Ha) yaitu: Ada mengetahui Hubungan Konsep Diri Terhadap Prestasi Belajar Pada Siswa Kelas VII SMP Negeri 2 Tanjung Kabupaten Lombok Utara. Sedangkan hipotesis nol (Ho) yakni: Tidak ada mengetahui Hubungan Konsep Diri Terhadap Prestasi Belajar Pada Siswa Kelas VII SMP Negeri 2 Tanjung Kabupaten Lombok Utara. 
2). Membuat Tabel Kerja

Tabel kerja untuk pengolahan data yang telah dikumpulkan dengan metode angket dan dokumentasi guna menguji hipotesis tentang Hubungan Antara konsep diri dengan prestasi belajar pada siswaSMP Negeri 2 Tanjung Kabupaten Lombok Utara.

Tabel 02. Tabel Kerja Untuk Menguji Hipotesis Tentang Hubungan Antara konsep diri dengan prestasi belajar Pada Siswa SMP Negeri 2 Tanjung Kabupaten Lombok Utara.

\begin{tabular}{|c|c|c|c|c|c|}
\hline No & $\mathbf{X}$ & $Y$ & XY & $\mathbf{X}^{2}$ & $\mathbf{Y}^{2}$ \\
\hline (1) & (2) & (3) & (4) & (5) & (6) \\
\hline 1 & 42 & 80 & 3360 & 1764 & 6400 \\
\hline 2 & 41 & 63 & 2583 & 1681 & 3969 \\
\hline 3 & 43 & 80 & 3440 & 1849 & 6400 \\
\hline 4 & 44 & 68 & 2992 & 1936 & 4624 \\
\hline 5 & 45 & 63 & 2835 & 2025 & 3969 \\
\hline 6 & 40 & 63 & 2520 & 1600 & 3969 \\
\hline 7 & 41 & 64 & 2624 & 1681 & 4096 \\
\hline 8 & 43 & 63 & 2709 & 1849 & 3969 \\
\hline 9 & 40 & 64 & 2560 & 1600 & 4096 \\
\hline 10 & 44 & 72 & 3160 & 1936 & 5186 \\
\hline 11 & 42 & 72 & 3024 & 1764 & 5184 \\
\hline 12 & 41 & 72 & 2952 & 1681 & 5184 \\
\hline 13 & 43 & 68 & 2924 & 1849 & 4624 \\
\hline 14 & 40 & 75 & 3000 & 1600 & 5625 \\
\hline 15 & 43 & 63 & 2709 & 1849 & 3969 \\
\hline 16 & 44 & 63 & 2772 & 1936 & 3969 \\
\hline 17 & 57 & 68 & 3876 & 3249 & 4624 \\
\hline 18 & 42 & 63 & 2646 & 1764 & 3969 \\
\hline 19 & 42 & 65 & 2730 & 1764 & 4225 \\
\hline 20 & 43 & 63 & 2709 & 1849 & 3969 \\
\hline
\end{tabular}




\begin{tabular}{|c|c|c|c|c|c|}
\hline 21 & 42 & 63 & 2646 & 1764 & 3969 \\
\hline 22 & 44 & 64 & 2816 & 1936 & 4096 \\
\hline 23 & 43 & 75 & 2750 & 1849 & 4096 \\
\hline 24 & 42 & 64 & 2646 & 1764 & 3969 \\
\hline 25 & 53 & 63 & 3869 & 2809 & 5329 \\
\hline 26 & 42 & 73 & 2646 & 1764 & 3969 \\
\hline 27 & 42 & 63 & 2646 & 1764 & 3969 \\
\hline 28 & 46 & 63 & 4800 & 2116 & 5625 \\
\hline 29 & 43 & 75 & 3354 & 1849 & 6084 \\
\hline 30 & 42 & 78 & 2688 & 1764 & 4096 \\
\hline 31 & 44 & 64 & 2772 & 1936 & 3969 \\
\hline 32 & 42 & 63 & 2646 & 1764 & 3969 \\
\hline 33 & 41 & 63 & 2583 & 1681 & 3969 \\
\hline 34 & 43 & 63 & 3225 & 1846 & 5625 \\
\hline 35 & 40 & 75 & 2600 & 1600 & 4225 \\
\hline 36 & 43 & 65 & 2709 & 1849 & 3969 \\
\hline 37 & 44 & 63 & 3168 & 1936 & 5184 \\
\hline 38 & 57 & 72 & 4902 & 3249 & 4624 \\
\hline 39 & 42 & 68 & 2646 & 1764 & 3969 \\
\hline 40 & 42 & 63 & 3024 & 1764 & 5181 \\
\hline 41 & 43 & 72 & 2709 & 1849 & 3969 \\
\hline 42 & 42 & 63 & 2856 & 1764 & 4624 \\
\hline 43 & 44 & 68 & 2772 & 1936 & 3969 \\
\hline 44 & 43 & 63 & 2709 & 1849 & 3969 \\
\hline 45 & 42 & 63 & 2646 & 1764 & 3969 \\
\hline 46 & 53 & 63 & 3339 & 2809 & 3969 \\
\hline 47 & 42 & 63 & 2646 & 1764 & 3969 \\
\hline 48 & 42 & 80 & 3360 & 1762 & 6400 \\
\hline 49 & 46 & 63 & 2898 & 2116 & 3969 \\
\hline 50 & 43 & 64 & 2752 & 1849 & 4096 \\
\hline
\end{tabular}




\section{$\sum x=2161$}

$\sum \mathbf{y}=\mathbf{3 3 5 4}$

$\sum x y=145300$

$\sum \mathbf{x}^{2}=\mathbf{9 5 4 5 6}$

$\sum \mathbf{y}^{2}=\mathbf{2 1 6 2 1 7}$

3) Memasukkan Data Ke Dalam Rumus.

Berdasarkan data tabel di atas, maka data-data tersebut dimasukkan ke dalam rumus koefisien korelasi product moment ini :

$$
\begin{aligned}
\mathrm{X} & =2161 \mathrm{X}^{2}=95456 \mathrm{Y}=3354 \mathrm{Y}^{2}=216217 \mathrm{XY}=145300 \\
\mathrm{r}_{\mathrm{xy}} & =\frac{\mathrm{N} \sum \mathrm{XY}-\left(\sum \mathrm{X}\right)\left(\sum \mathrm{Y}\right)}{\sqrt{\left(\mathrm{N} \sum \mathrm{X}^{2}-\left(\sum \mathrm{X}\right)^{2}\right)\left[\mathrm{N} \sum \mathrm{Y}^{2}-\left(\sum \mathrm{Y}\right)^{2}\right]}} \quad=\frac{50.145300-(2161) .(3354)}{\sqrt{\left[50.95456-(2161)^{2}\right][50.21617-(3354]}} \\
& =\frac{7265000-7247994}{\sqrt{[4772800-108050][4669921-11249316]}}=\frac{17006}{\sqrt{4664750-6579395}}=\frac{17006}{\sqrt{30691233}} \\
= & \frac{17006}{5539,96} \quad=3,070
\end{aligned}
$$

4) Menguji Nilai Korelasi Product Moment

Berdasarkan hasil perhitungan di atas, ternyata Nilai $r_{x y}$ yang dihasilkan dengan rumus Product Moment dengan taraf "Signifikan" 5\% dengan N=50 dalam penelitian ini adalah sebesar $=3,070$, sedangkan $r_{\text {tabel }}=0.279,\left(r_{\text {hitung }}>r_{\text {tabel }}\right)$ yaitu $(3,070>0.279)$ yang dinyatakan "Signifikan". Ini berarti hipotesis Alternatif (Ha) diterima, sedangkan Hipotesis Nihil (Ho) ditolak.

5) Menarik Kesimpulan Analisis

Karena nilai $r$ hitung pada penelitian ini dinyatakan "Signifikan", dengan taraf "Signifikansi"5\% maka kesimpilan yang diperoleh dalam penelitian ini ada Hubungan Antara konsep diri dengan prestasi belajar pada siswa belajar siswa SMP Negeri 2 Tanjung Kabupaten Lombok Utara.

\section{PEMBAHASAN}

Berdasarkan pada hasil analisis di atas, dimana nilai $\mathrm{r}$ peoduct moment hasil penelitian setelah diperoleh nilai $r$ hitung dengan $\mathrm{N}=50$, dalam penelitian ini adalah sebesar $=3,070$ sedangkan $r$ tabel dengan taraf signifikan $5 \%$ pada $\mathrm{N}=50$ harga tabel $=0,279$ ini menunjukkan bahwa nilai $\mathrm{r}$ tabel, atau ( $\mathrm{r}$ hitung $>\mathrm{r}$ tabel) yaitu $(3,070>0,0279)$ yang menyatakan bahwa hipotesis alternatif $(\mathrm{Ha})$ yang diajukan diterima dan sebaliknya hipotesis nihil (Ho) yang diajukan ditolak yang artinya bahwa hasil penelitian ini adalah "signifikan". Dengan kata lainHal 
ini menunjukkan ini ada hubungan konsep diri dengan prestasi belajar pada siswa SMP Negeri 2 Tanjung Lombok Utara, bahwa nilai $\mathrm{r}$ tabel, atau ( $\mathrm{r}$ hitung > r tabel) yaitu $(3,070>0.279)$, yang menyatakan bahwa hipotesis alternatif $(\mathrm{Ha})$ yang diajukan diterima dan sebaliknya hipotesis nihil (Ho) yang diajukan ditolak yang artinya bahwa hasil penelitian ini adalah "signifikan".

\section{SIMPULAN}

Setelah dilaksanakan analisis data diperoleh hasil penelitian atau $r$ hitung $\mathrm{N}=50$ dalam penelitian ini adalah sebesar $=3,070$ sedangkan $r$ tabel dengan taraf signifikan 5\% pada $\mathrm{N}=50$ menunjukkan harga $\mathrm{r}$ tabel=0,279, ini menunjukkan bahwa nilai $\mathrm{r}$ tabel, atau ( $\mathrm{r}$ hitung $>\mathrm{r}$ tabel) yaitu $(3,070>0,279)$, hipotesis alternatif (Ha) diterima sedangkan hipotesis nihil (Ho) ditolak. Yang berarti hasil penelitian ini adalah "signifikan", dengan demikian dapat ditarik kesimpulan bahwa Ada hubungan antara konsep diri dengan prestasi belajar pada siswa SMP Negeri 2 Tanjung Lombok Utara, artinya siswa yang memiliki konsep diri yang positif perilaku memiliki prestasi belajar yang baik di sekolah. Jadi kesimpulanya adalah sebagai berikut: Ada hubungan antara konsep diri dengan prestasi belajar pada siswa SMP Negeri 2 Tanjung Lombok Utara.

\section{DAFTAR PUSTAKA}

Arikunto, Suharsimi. 2002. Prosedur Penelitian Suatu Pendekatan Praktek.Jakarta : Rineka Cipta.

Alex sobur.2003.psikologi umum. Bandung : CV Pustaka Setia.

Djamarah, S, Bahri. 2012. Prestasi Belajar dan Kompetensi Guru.Surabaya: Usaha Nasional

Https://bawana.wordpress.com/2008/04/19/aspek-aspek-dalam-konsep-diri/

Muhibbin, S. 2011. Psikologi Pendidikan: Dengan Pendekatan Baru. Bandung: Remaja Rosdakarya

Rahmat, Jalaluddin. 2005. Psikologi Komunikasi. Bandung : RemajaRosdakarya.

Sugiyo. 2005. Komunikasi Antar Pribadi. Semarang : Unnes Press.

Sugiyono. 2010. Metode Penelitian Kuntitatif Kualitatif dan $R \&$ D. Bandung: Alfabeta

Sudjana, 1992 Media Pengajaran dan Pembuatannya, Bandung: Sinar.

Sri Narti, 2014. Medel bimbingan kelompok berbasis ajaran islam untuk meningkatkan konsep diri siswa. Pustaka Belajar.: Yogyakarta.

Priansa, D. 2015.Manajemen Peserta Didik Dan Model Pembelajaran; Cerdas, Kreatif dan Inovatif. Bandung: Alfabeta CV 